\title{
PKM Pelatihan Kosakata Bahasa Inggris Melalui Media Audio-Visual Bagi Santri di Asrama Excellent Language Organization [EXO] MAN 1 Probolinggo
}

Mochlis Ekowijayanto, ${ }^{1}$ Tiara Ainur Rizki, ${ }^{2}$ Siti Kholilatul Jannah, ${ }^{3}$ Sheila Rohmaniyah, ${ }^{4}$ Nurlailiya Fitriana, ${ }^{5}$ Rozanatul Hamimah Fauzi, ${ }^{6}$ Munisa Imamah

Universitas Nurul Jadid, Paiton ${ }^{1234567}$

Submission: 31/07/2021 Received: 30/08/2021 Published: 31/12/2021

\section{Keywords: \\ Learn English, Vocabulary Audio-Visual}

\begin{abstract}
English learning from conventional ways to technologybased learning is well known today. It is necessary to know the efforts to use technology against the performance of students. One of the technologies that is currently popular is audio-visual.This training activity aims to improve the vocabulary of students after learning English using audio-visual. The participants of this training are students who live in the excellent language organization [EXO] MAN 1 Probolinggo dormitory. The results of this training activity are expected to provide motivation for students in the use of audiovisual media and can increase a high sense of learning interest and improve vocabulary mastery in English.
\end{abstract}

Katakunci: Pembelajaran Bahasa Inggris, Kosakata, Audio-Visual.

\begin{abstract}
Abstrak. Pembelajaran bahasa Inggris dari cara konvensional untuk pembelajaran berbasis teknologi terkenal saat ini. Hal ini diperlukan untuk mengetahui upaya penggunaan teknologi terhadap kinerja santri. Salah satu teknologi yang saat ini popular dilakukan adalah audio-visual. Kegiatan pelatihan ini bertujuan untuk meningkatkan kosa-kata santri setelah belajar bahasa Inggris menggunakan audio-visual. Peserta pelatihan ini adalah santri yang berdomisili di asrama Excellent Language Organization [EXO] MAN 1 Probolinggo. Hasil dari kegiatan pelatihan ini diharapkan mampu memberikan motivasi tersendiri bagi santri dalam meningkatkan pemerolehan kosa-kata menggunakan media audio-visual serta dapat memiliki ketertarikan belajar yang cukup tinggi untuk meningkatkan penguasaan kosa-kata dalam bahasa Inggris.
\end{abstract}

\section{Pendahuluan}

Bahasa Inggris merupakan salah satu bahasa Internasional yang dipelajari hampir setiap negara karena menganggap bahwa Bahasa Inggris adalah bahasa pemersatu. Setiap negara memiliki Bahasa yang berbeda-beda itulah yang menunjukkan ciri khas dan budaya mereka. Namun, ada satu bahasa yang terpilih sebagai Bahasa internasional yaitu bahasa Inggris. Bahasa adalah suatu sistem lambang, seperti halnya bunyi yang mempunyai sifat arbitrer 
yang digunakan oleh setiap anggota kelompok sosial untuk bekerja sama, berkomunikasi diri sedangkan fungsi utama bahasa adalah sebagai alat komunikasi antar manusia (Sitepu \& Rita, 2017).

Media merupakan alat yang dapat digunakan dalam menyampaikan sesuatu. Dalam proses pembelajaran, media dijadikan sebagai perantara dalam berkomunikasi (Sultan \& Subair, 2005). Untuk mempermudah berkomunikasi tentunya diperlukan penguasaan kosakata. Namun, sebaiknya mengajarkan kosakata sejak usia dini karena daya ingat seorang anak sangat kuat, itulah sebabnya usia dini disebut sebagai masa keemasan (Golden age). Namun tidak sedikit peserta didik menganggap bahwa belajar bahasa Inggris itu sulit karena setiap kalimat yang di utarakan harus sesuai tata bahasanya padahal pada hakikatnya tidak sesulit yang mereka duga. Manfaat penggunaan media audio-visual mampumeningkatkan gairah belajar bagi santri, menghadirkan suasana yang santai, hal terpenting santri mampu belajar meningkatkan kosakata bahasa Inggris dengan senang hati (Ratminingsih, 2016).

Dengan memiliki kemampuan bahasa Inggris yang baik tentu akan mendapatkan kesempatan untuk mendapatkan ilmu pengetahuan yang lebih layak lagi. Untuk bisa memahami bahasa Inggris dengan baik, tentunya harus diimbangi dengan penguasaan kosakata yang cukup. Dalam pembelajaran bahasa Inggris, proses belajar awal yang harus dilakukan dimulai dengan hal terkecil yaitu kosakata. Penggunaan media yang menarik dan atraktif sangat diperlukan dalam belajar untuk menambah pembendaharaan kosakata. Pembelajaran bahasa Inggris di era digital ini harusnya juga mengikuti perkembangan media yang digunakan sebagai alat yang membantu mempermudah proses pembelajaran salah satunya dengan audio-visual. Penggunaan media audio-visual mampu menghadirkan solusi bagi santri dalam belajar bahasa Inggris khususnya dalam pemerolehan kosakata (Faizah \& Gumiandari, 2021).

Langkah awal untuk bisa berkomunikasi dengan bahasa Inggrissantri harus menguasai banyak kosakata karena kosakata dapat memperlancar seseorang dalam berbicara. Dengan demikian perlu diadakan pelatihan sebagai dasar pengenalan peningkatan kosakata terhadap peserta didik. Pelatihan ini juga akan mempermudah dalam memilih metode pembelajaran. Banyak metode pembelajaran yang digunakan seorang guru seperti metode membaca, 
menulis, mendengarkan, dan menonton (Hasibuan, 2013). Namun kebanyakan peserta didik lebih menyukai hal dalam menyimak. Sedangkan seorang pendidik hendaknya pandai dalam menentukanmetode pembelajaran yang atraktif. Salah satu cara metode yang paling efektif dan menarikyaitu dengan menggunakan media audio-visual dalam mengenalkan kosakata(Sueni, 2019). Harapan dengan diadakannya pelatihan ini dapat mencetak santri dengan minat dan kemampuan bahasa Inggris yang memadai. Bahasa Inggrismerupakan pelajaran wajib yang diberikan oleh setiap sekolah sehingga santri/siswimemiliki cukup bekal untuk melanjutkan ke jenjang yang lebih tinggi nantinya.

Oleh sebab itu,minimnya penggunaan metode pembelajaran yang digunakan khususnya dalam penguasaan kosakata bahasa Inggris di ASRAMA EXCELLENT LANGUAGE ORGANIZATION [EXO] MAN 1 PROBOLINGGO, maka sebagai salah satu bentuk perhatian kelompok pengabdian dari mahasiswa KKN program studi Pendidikan bahasa Inggris(PBI) yaitu melaksanakan pengabdian untuk menyampaikan metode pembelajaran bahasa Inggrisyang menarik dan memberikan pelatihan penggunaan metode pembelajaran tersebut dengan judul pengabdian "Pelatihan Kosakata Bahasa Inggris Melalui Media Audio-Visual Bagi Santri di Asrama Excellent Language Organization [Exo] Man 1 Probolinggo."

\section{Metode}

Dalam kegiatan pengabdian kepada masyarakat (PkM) ini, metode yang digunakan adalah perpaduan antara metode ceramah dan praktikum untuk mengetahui sejauh mana pelatihan ini memberikan dampak terhadap peningkatan kosakata bagi santri. Tujuan penggunaan metode ceramah yaitu untuk memberikan stimulus bagi santri terhadap apa yang kemudian akan tim lakukan dalam kegiatan ini, pemahaman tentang audio-visual dan penggunaannya, materi tentang kosakata yang digunakan dalam kegiatan ini disesuaikan dengan kebutuhan santri nantinya. Kemudian metode praktik digunakan untuk memberikan kesempatan bagi santri untuk praktik secara langsung tentang cara peggunaan kosakata bahasa Inggristersebut dalam kehidupan sehari-hari. 
Kegiatan Pengabdian Kepada Masyarakat (PkM) yang dilakukan oleh mahasiswa prodi Pendidikan Bahasa Inggris (PBI) yaitu melakukan pelatihan bagi santri yang berdomisili di asrama Excellent Language Organization [EXO] MAN 1 Probolinggo. Kegiatan PkM mahasiswa Pendidikan Bahasa Inggris (PBI) Universitas Nurul Jadid ini dilaksanakan pada tanggal 11 April 2021,bertempat di Aula MAN 1 Probolinggo. Kegiatan ini dapat dilihat pada Gambar 1.

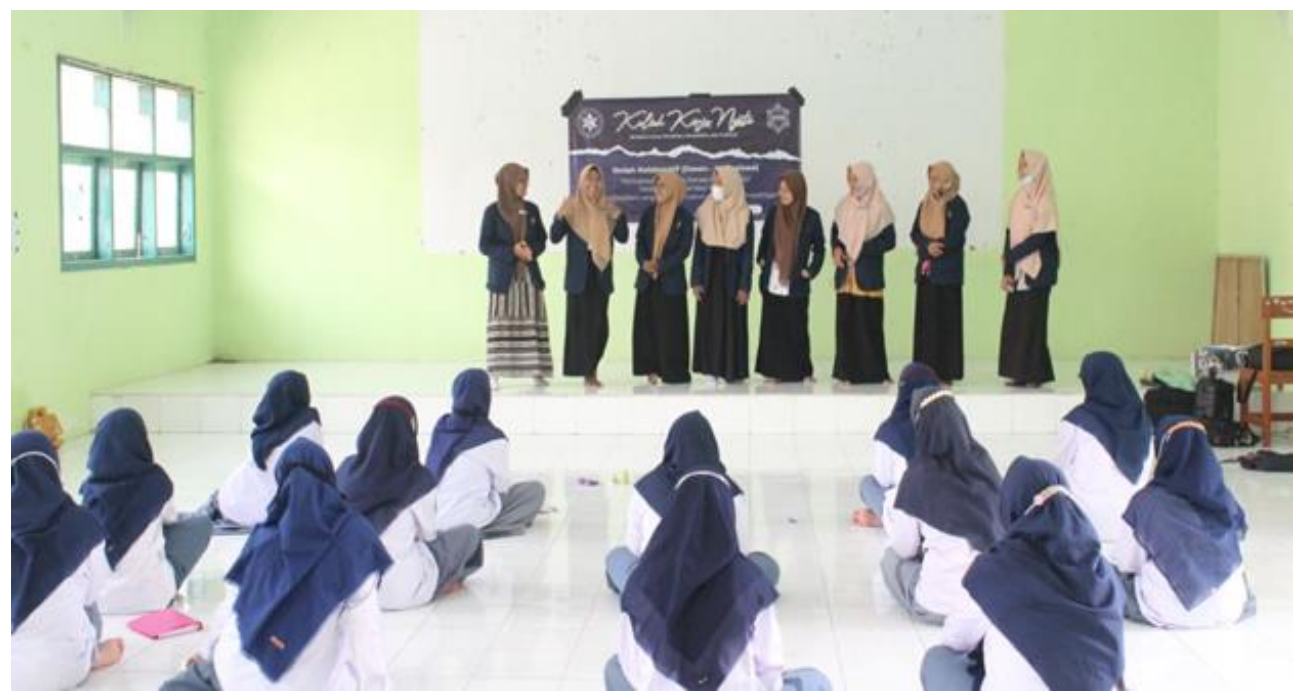

Gambar 1. Alur proses kegiatan pelaksanaan PkM oleh mahasiswa prodi Pendidikan Bahasa Inggris (PBI) Universitas Nurul Jadid seperti yang terlihat pada Gambar 2 dibawah ini.

\section{ALUR PELAKSANAAN PKM}

\begin{tabular}{|c|c|c|c|}
\hline \multicolumn{4}{|l|}{ Start } \\
\hline \multicolumn{4}{|c|}{ Pembentukan Tim Pengabdian } \\
\hline Step 1 & Step 2 & Step 3 & Step 4 \\
\hline $\begin{array}{l}\text { Perumusan } \\
\text { Tujuan }\end{array}$ & $\begin{array}{l}\text { Analisis } \\
\text { Kebutuhan }\end{array}$ & $\begin{array}{c}\text { Penentuan } \\
\text { Solusi Masalah }\end{array}$ & $\begin{array}{c}\text { Persiapan } \\
\text { Kegiatan PkM }\end{array}$ \\
\hline Step 5 & Step 6 & Step 7 & Step 8 \\
\hline Implementasi & Pendampingan & $\begin{array}{c}\text { Review dan } \\
\text { Evaluasi }\end{array}$ & Selesai \\
\hline
\end{tabular}

Gambar 2. Alur Pengabdian Kepada Masyarakat 
Kegiatan PkM dimulai dengan pembentukan tim PkM yang terdiri dari 8 mahasiswa aktif yang sedang menempuh Kuliah Kerja Nyata (KKN). Kemudian merumuskan tujuan, analisa kebutuhan PkM seperti ketersediaan tempat yang akan digunakan ketika kegiatan berlangsung. Setelah itu menentukan solusi masalah yang akan ditawarkan, proses persiapan materi pelatihan kosakata bagi santridengan mempersiapkanmodulpelatihan, audio-visual (short movie) yang sesuai dan lainnya.. Tahap implementasi acara pelatihan yang dilaksanakan diaula MAN 1 Probolinggo serta dilakukan pendampingan oleh bapak Mochlis Ekowijayanto selaku dosen pembimbing KKN 2021 dalam menentukan materi pelatihan yang sesuai dengan kebutuhan santri di asrama Excellent Language Organization [EXO] MAN 1 Probolinggo. Kemudian setelah kegiatan PkM selesai dalam bentuk pelatihan kosa-kata, maka tim melakukan review terhadap kegiatan PkM dan melakukan evaluasi untuk menentukan solusi dari permasalahan yang dihadapi kegiatan PkM berlangsung.

\section{Hasil}

Untuk melancarkan kegiatan PkM ini, mahasiswa KKN 2021 sebagai tim pengabdian masyarakat terlebih dahulu melaksanakan koordinasi dengan dosen pempimbing dan LP3M Universitas Nurul Jadid untuk membuatkan surat pengantar untuk mitra terkait waktu pelaksaanan pengabdian yang akan dilaksanakan, setelah mendapatkan kesepakatan selanjutnya kami meminta izin kepada pihak MAN 1 Probolinggo untuk menggunakan kelas kosong dan peminjaman LCD untuk memudahkan proses kegiatan PkM tersebut. Proses kegiatan pengabdian bisa dilihat pada gambar 3 . 


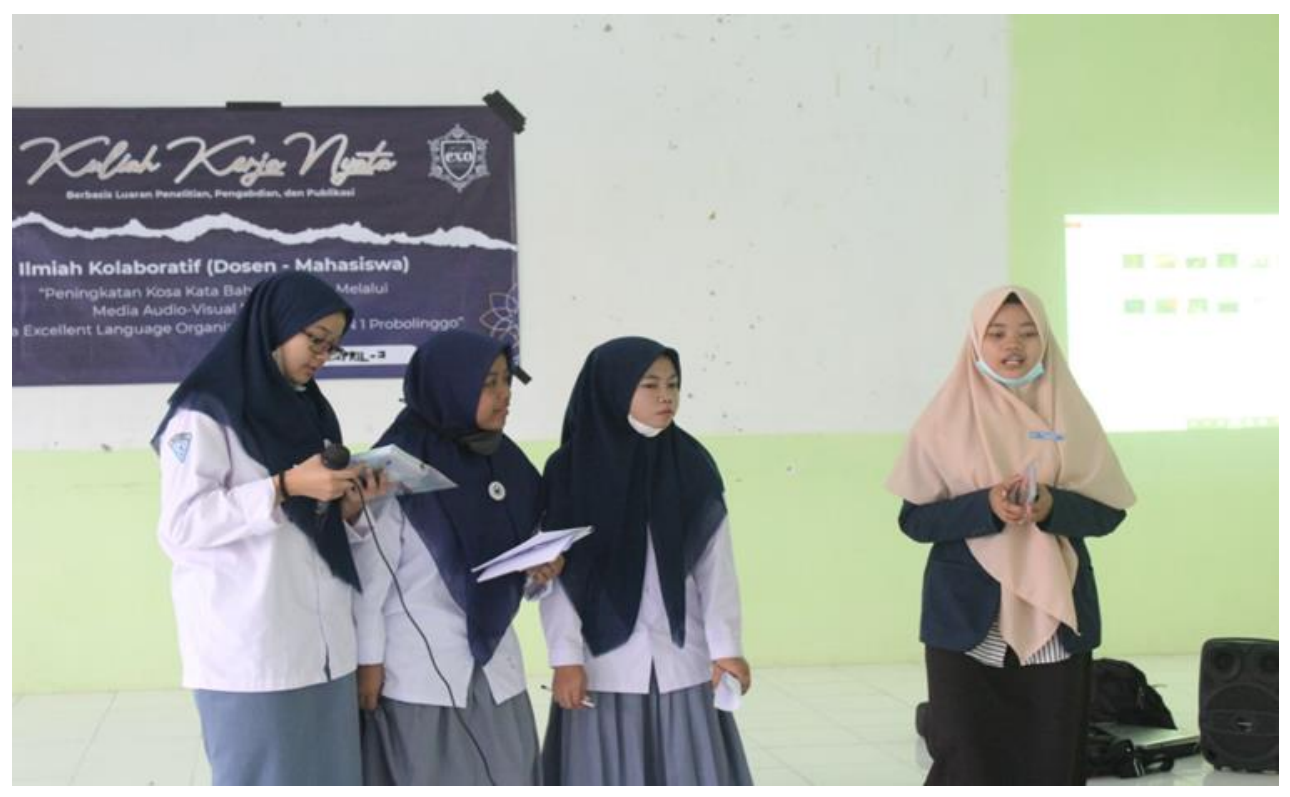

Gambar 3. Proses Pelatihan Kosakata bagi Santri

Proses peningkatan kosakata Bahasa Inggris ini berupa kegiatan pelatihan yang dilaksanakan di kelas melalui media audio-visual yang berupa short movie Bahasa Inggris yang mana siswi diberikan kesempatan untuk menyimak sekaligus mendengarkan kosakata Bahasa Inggris yang terdapat dalam short movie tersebut dan menuliskan kosakata yang baru mereka ketahui ke dalam buku tulis lalu siswi diberi tugas untuk memaknai (translate) berdasarkan kamus lalu siswi diminta untuk melafalkannya di depan kelas.

Setelah siswi diyakini telah mampu menyimak sekaligus mendengarkan kosakata yang ada dalam short movie tersebut sehingga siswi dapat menemukan kosakata yang belum pernah ia ketahui sebelumnya, lalu tim membimbing santri/siswi agar dapat mengetahui maknanya dengan membantu siswi memaknai kosakata yang baru diketahuinya dengan berdasarkan kamus sehingga, dalam hal ini jelas kosakata bahasa Inggrissantri/siswi akan meningkat secara individu.

Kemudian santri/siswi diminta untuk melafalkan kosakata yang telah ia ketahui maknanya dengan suara lantang di depan kelas.Lalu siswi lainnya diminta untuk menulis dibuku masing-masing lalu mengikuti apa yang telah dilafalkannya tadi. Dengan begitu semua santri/siswi yang mengikuti kegiatan 
pelatihan ini mudah meningkatkan kosakata Bahasa Inggris secara baik dan benar.

Tahap berikutnya, memperhatikan siswi mampu mengulang kembali beberapa kosakata yang disampaikan oleh tim, kemudian tim memberitahukan setiap makna pada kosakata tersebut. Kemudian setelah pemutaran short movie, santri/siswi diberi kesempatan untuk menyebutkan setiap makna dari kosakata bahasa Inggris dari auido-visual tersebut. Penyampaian pesan pembelajaran bahasa Inggris dengan menggunakan media audio-visual untuk santri begitu terlihat hasilnya dalam peningkatan kosakata baru yang belum pernah diketahui sebelumnya (Misbah, Surya, \& Maskur, 2017).

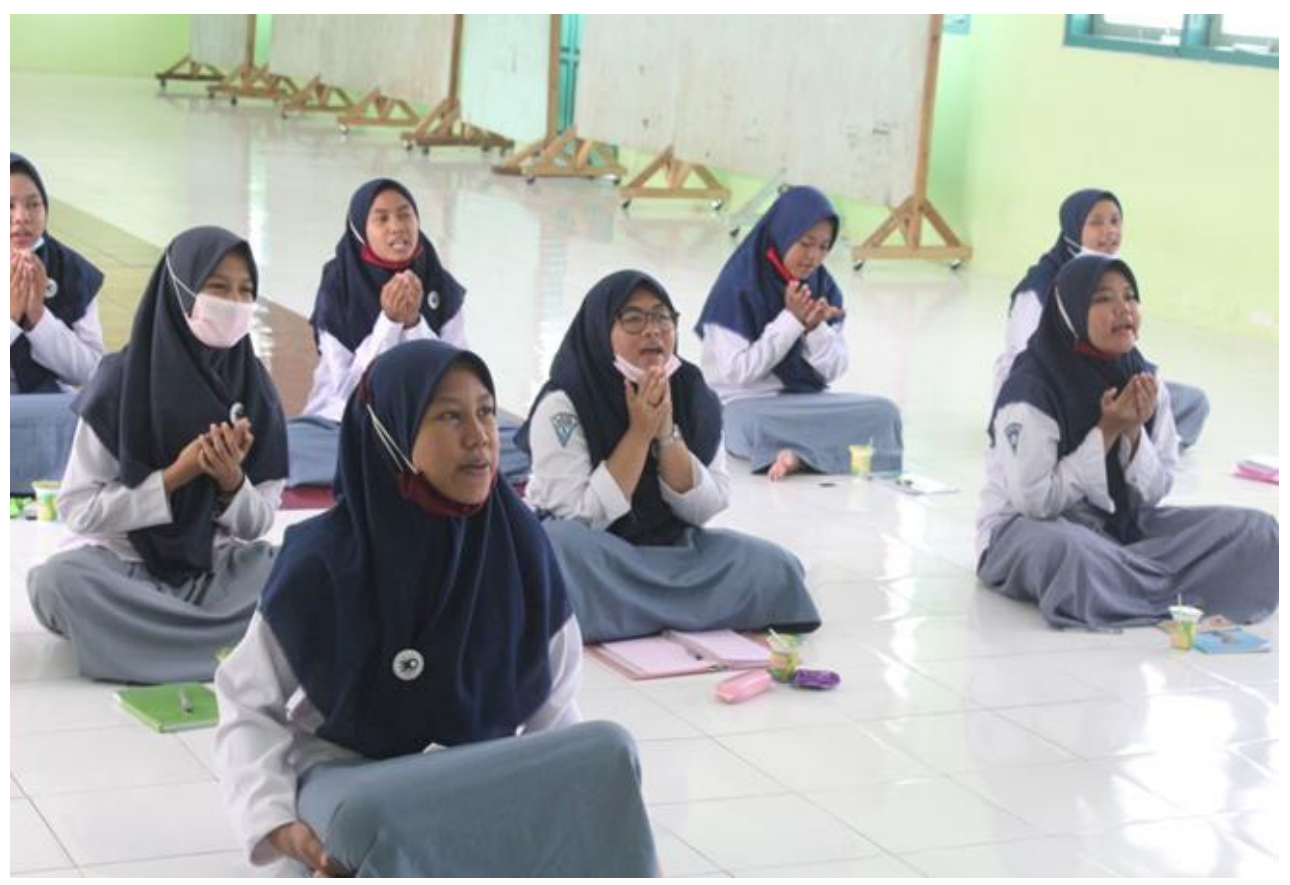

Gambar 4. Proses praktik pengulangan kosakata

Penghujung pelatihan tim pengabdian memberikan sesi tanya jawab untuk mengasah pengetahuan siswi. Dari kegiatan yang kami laksanakan ini sangat diapresiasi dengan cukup baik oleh para santri hal ini dapat di buktikan dimana saat proses kegiatan, para santri sangat antusias dalam mengikuti proses kegiatan ini. 


\section{Pembahasan}

Kegiatan observasi dan evaluasi terhadap santri dilakukan untuk mengetahui perkembangan santri setelah kegiatan pengabdian tersebut. Tujuan dilakukannya kegiatan observasi ini adalah untuk mengamati tingkat kepekaan santri terhadap materi pembelajaran bahasa Inggris yang sudah diberikan menggunakan media audio-visual. Meskipun pada kenyataannya tidak semua santri yang dapat menangkap setiap materi yang telah diberikan dikarenakan proses pengabdian yang dilakukan oleh mahasiswa PBI Universitas Nurul Jadid terbatas oleh waktu yang telah ditetapkan. Di penghujung kegiatan pengabdian dengan cara memberikan tanya jawab (feedback) secara lisan kepada santri terkait kosakata yang telah diberikan(Budianto, 2019).

Tindak lanjut dari evaluasi tersebut kemudian didiskusikan dibahas secara menyeluruh bersama stakesholder yang terlibat terutama pengurus yang di asrama dan mahasiswa selaku tim pengabdian. Hasil dari diskusi terkait evaluasi kegiatan pengabdian kemudian diberikan solusi atas setiap kelemahan yang dihadapi oleh santri dalam peningkatan kosakata melalui audio-visual. Sehingga kegiatan pengabdian masyarakat ini memberikan pengaruh yang cukup besar dalam peningkatan kosakata dalam bahasa Inggris pada santri di Asrama Excellent Language Organization (Exo) MAN 1 Probolinggo (Lubis, 2014).

\section{Kesimpulan}

Berdasarkan hasil kegiatan dapat ditarik kesimpulan mengenai pelatihan kosa-kata bahasa Inggris melalui media audio-visual bagi santri di asrama Excellent Language Organization [EXO] MAN 1 Probolinggo sebagai berikut.

Pelaksanaan pelatihan kosakata bahasa Inggris melalui media audio-visual bagi santri di asrama Excellent Language Organization [EXO] MAN 1 Probolinggo telah dilaksanakan denganbaik. Kegiatan pengabdian kepada masyarakat oleh mahasiswa Pendidikan Bahasa Inggris (PBI) Universitas Nurul Jadid telah dilakukan sesuai dengan perencanaan, yakni dengan melaksanakan kegiatan dan mengamati setiap perkembangan dan kemampuan santri/siswi dalam belajar kosakata bahasa Inggris. Kegiatan pelatihan peningkatan kosakata ini diharapkan mampu memberikan 
semangat bagi santri dalam belajar bahasa Inggris dilingkungan Pondok Pesantren.

\section{Pengakuan}

Kami segenap tim mahasiswa KKN tahun 2021 mengucapkan rasa syukur dan terimakasih kepada: Allah SWT yang telah memberi kita rahmat serta hidayahnya hingga bisa melaksanakan salah satu Tridharma Perguruan Tinggi yaitu kegiatan pengabdian kepada masyarakat ( $\mathrm{PkM}$ ) ini dengan baik dan lancar, Pengasuh Pondok Pesantren Nurul Jadid KH. Moh. Zuhri Zaini, B.A, Rektor Universitas Nurul Jadid KH. Abdul Hamid Wahid, M.Ag, Bapak Achmad Fawaid, M.A, M.A selaku Kepala LP3M Universitas Nurul Jadid, Bapak Dr. Tirmidi selaku Dekan Fakultas Sosial dan Humaniora dan seluruh mahasiswa yang ada di FakultasSosial dan Humaniora Universitas Nurul Jadid. Semoga kegiatan pengabdian ini memberikan manfaat bagi mahasiswa KKN dan bagi Santri yang berdomisili di asrama Excellent Language Organization [EXO] MAN 1 Probolinggo.

\section{Referensi}

Budianto, S. (2019). KOSAKATA BAHASA INGGRIS UNTUK ANAK MELALUI MEDIA. 165-168.

Faizah, N., \& Gumiandari, S. (2021). EFEKTIVITAS MEDIA AUDIO DAN VISUAL TERHADAP PEMBELAJARAN KOSAKATA BAHASA INGGRIS TINGKAT SD( Studi Kasus Pada TPQ Al-Huda ). 6.

Hasibuan, N. (2013). Kriteria Pemilihan Metode Mengajar dalam Kegiatan Pembelajaran. Ta'allum: Jurnal Pendidikan Islam, 1(1). https://doi.org/10.21274/taalum.2013.1.1.37-48

Lubis, E. (2014). Pengaruh media audio visual terhadap peningkatan kosakata anak usia 4-5 tahun. 1-11.

Misbah, D., Surya, M., \& Maskur. (2017). Penggunaan Media Audio Visual Dalam Pembelajaran Yang Berbasis Power Point Model Pop Up Untuk Meningkatkan Hasil Belajar Siswa Pada Materi Kosakata Mata Pelajaran Arab. Jurnal Teknologi Pendidikan Dan Pembelajaran, 2(September), 404-417. 
Ratminingsih, N. M. (2016). Efektivitas Media Audio Pembelajaran Bahasa Inggris Berbasis Lagu Kreasi Di Kelas Lima Sekolah Dasar. JPI (Jurnal Pendidikan Indonesia), 5(1), 27. https://doi.org/10.23887/jpiundiksha.v5i1.8292

Sitepu, T., \& Rita. (2017). Bahasa Indonesia Sebagai Media Primerkomunikasi Pembelajaran. Pendidikan Bahasa Dan Sastra Indonesia, 2(1), 67-73.

Sueni, N. M. (2019). Metode, Model dan Bentuk Model Pembelajaran. Wacana Saraswati, 19(2), 1-16. Retrieved from https://jurnal.ikipsaraswati.ac.id/index.php/wacanasaraswati/article/v iew/35

Sultan, M. A., \& Subair, A. (2005). Pelatihan peningkatan kosakata Bahasa Inggris menggunakan YouTube. 533-535. 